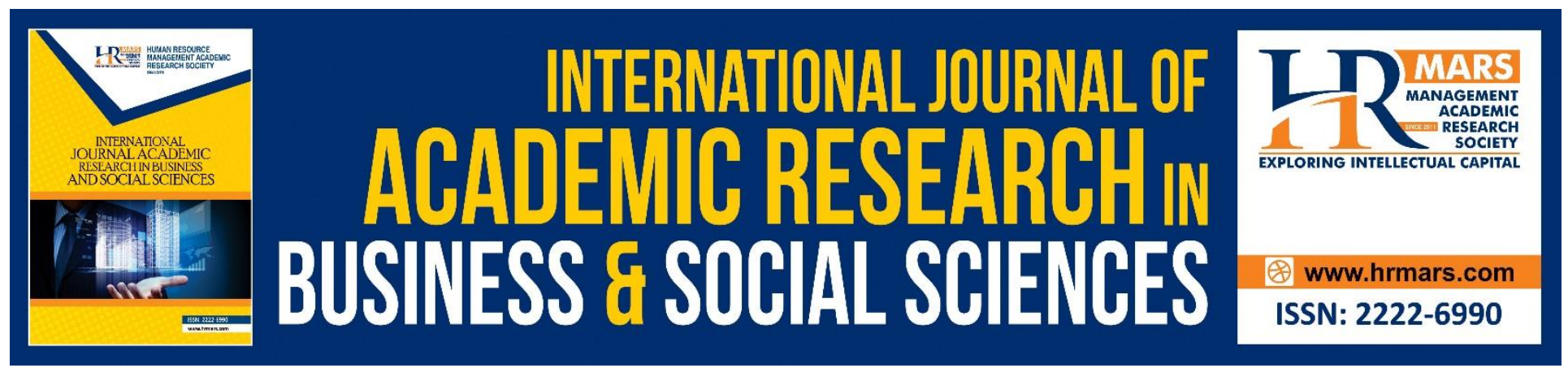

\title{
Determining Factors Influence Out-of-Pocket Health Expenditure among the Low-Income Group in Malaysia
}

Rusmawati Said, Norfatihah Isamail and Normaz Wana Ismail

To Link this Article: http://dx.doi.org/10.6007/IJARBSS/v10-i10/7740

DOI:10.6007/IJARBSS/v10-i10/7740

Received: 26 July 2020, Revised: 21 August 2020, Accepted: 19 September 2020

Published Online: 20 October 2020

In-Text Citation: (Said, Isamail, and Ismail, 2020)

To Cite this Article: Said, R., Isamail, N., and Ismail, N. W. (2020). Determining Factors Influence Out-of-Pocket Health Expenditure among the Low-Income Group in Malaysia. International Journal of Academic Research in Business and Social Sciences. 10(10), 292-311.

\section{Copyright: (c) 2020 The Author(s)}

Published by Human Resource Management Academic Research Society (www.hrmars.com)

This article is published under the Creative Commons Attribution (CC BY 4.0) license. Anyone may reproduce, distribute, translate and create derivative works of this article (for both commercial and non-commercial purposes), subject to full attribution to the original publication and authors. The full terms of this license may be seen

at: http://creativecommons.org/licences/by/4.0/legalcode

\section{Vol. 10, No. 10, 2020, Pg. 292 - 311}

Full Terms \& Conditions of access and use can be found at http://hrmars.com/index.php/pages/detail/publication-ethics 


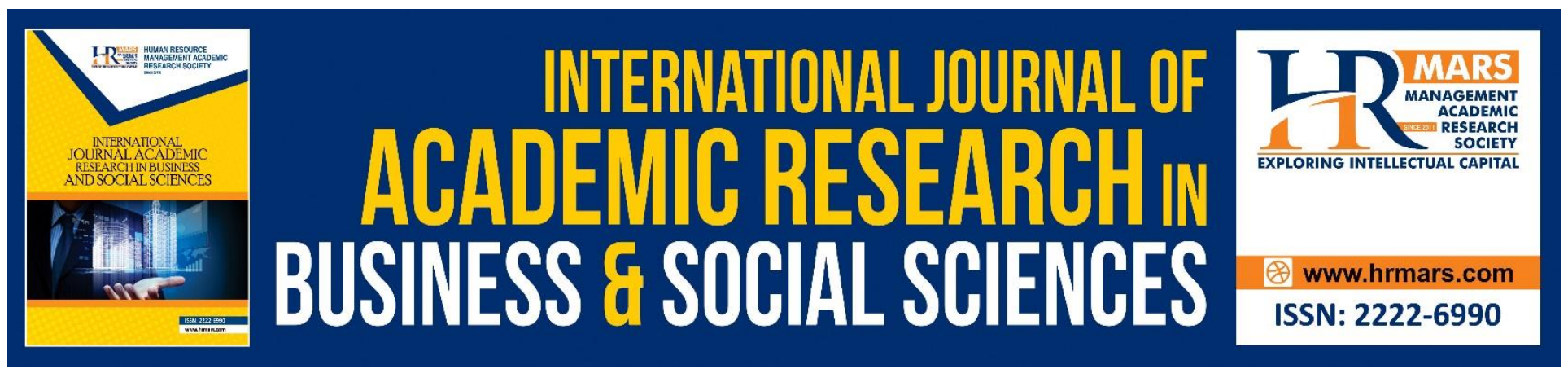

\title{
Determining Factors Influence Out-of-Pocket Health Expenditure among the Low-Income Group in Malaysia
}

\section{Rusmawati Said, Norfatihah Isamail and Normaz Wana Ismail}

School of Business and Economics, University Putra Malaysia (UPM), 43400 Serdang, Selangor Email: rusmawati@upm.edu.my

\begin{abstract}
A substantial proportion of the population is still struggling to achieve socio-economic and good health, i.e., the low-income groups. The low-income group in Malaysia might bear a higher burden of out-of-pocket health expenditure (OOPHE) and health challenges, mainly related to noncommunicable diseases (NCD). The costs are sometimes high enough so that households cannot recuperate them from existing resources and lead them to financial problems. This study analyzed the factors associated with OOPHE among B40 group in Malaysia using nationwide data from the 2015 National Health and Morbidity Survey (NHMS). Ordinary Least Square (OLS) regression analysis is used to study the factors associated with OOPHE. This study suggests that the gender (female) of household, income, T20 income group, tertiary education, unpaid worker, retire, and NCD raises the likelihood of incurring OOPHE. The result for a private employee, self-employed, and insurance status is spending less on OOPHE. Therefore, the results show a clear need for government action to enhanced primary healthcare programs and a focus on achieving Universal Health Coverage. This situation can protect the household from OOPHE financial burden and NCD, exceptionally lowincome earners.
\end{abstract}

Keywords: Out-of-pocket Payment, Healthcare Spending, Ordinary Least Square Regressions, LowIncome, Malaysia.

\section{Introduction}

The Malaysian Government is committed to helping its people in need, especially the low-income group. The low-income are still struggling to achieve socio-economic and good health quality due to inadequate income. During the 10th Malaysia Plan, the bottom 40 (B40) consists of 2.4 million households, while in the 11th Malaysia Plan, there are 2.7 million households of B40 (mean monthly income of RM2,537.00) (Jayasooria, 2016). The income group in Malaysia can divide into three main groups that consisting of B40 representing the bottom $40 \%$ of income earners, M40 is the middle $40 \%$, and T20 is the top $20 \%$ of income earners (DOSM, 2019). Socio-economic problems, health 
costs, and chronic diseases such as non-communicable diseases (NCD) continue to be the problems of the low-income group or B40. NCD can result in high OOPHE due to frequent treatment and a more extended stay at the hospital. It also imposes a substantial financial burden, especially to low-income groups (Pandey, Clarke, Dandona, \& Ploubidis, 2018).

NCD now contributes to an estimated $73 \%$ of Malaysia's total deaths (NHMS, 2015). The B40 group suffers from NCD burden, and it reflects on $47.6 \%$ of the B40 group aged 40 above suffer from a least one NCD that has not yet been diagnosed (NHMS, 2015). NCD is also known as chronic diseases, consists of cardiovascular diseases (such as heart attacks and strokes), cancers, chronic respiratory, diabetes mellitus, chronic kidney disease, and neurological disorders (Koris et al., 2019). NCD requires prolonged care and high treatment costs then will place a substantial financial burden on the household. The prevalence NCD trend is lower for the top income quintile, and the percentage increase from quintile five to the lowest quintile (quintile one) (NHMS, 2015). This trend reflects that low household groups face higher unaffordable healthcare services due to NCD compared to other income groups.

The Malaysian Government has introduced various programs to meet the needs and help the B40 group. Here are some of the ones that have been introduced, including Household Living Aid(BSH), The B40 National Protection Scheme (mySalam), and the Health Care Scheme for Group $B 40$ (PeKaB40, 2020). All this aid aims explicitly to protect and economically help the B40 group. BSH is the cash aid given to the household qualified according to a set of criteria announced by the Government. mySalam is a national health protection scheme aimed at providing free takaful (equivalent to insurance) health protection to $\mathrm{B} 40$ individuals who are also the recipients of the Household Living Aid (BSH). While PeKa B40 is a Government initiative through the Ministry of Health Malaysia $(\mathrm{MOH})$, which aims to cater to the low-income group's health needs, focusing on NCD. PeKa B40 is offered to Malaysians within the lowest $40 \%$ household income, known as the B40 group.

Although the Government heavily subsidized treatment in public healthcare services, some of the medical equipment costs are still borne by the patient, such as the costs for cardiac pacemakers, spinal implants, etc. This situation adds to the financial burden of those who are already less well-off. A more significant proportion of medical expenses contribute from OOPHE, the financial burden of healthcare services on low-income households is more severe (Chiang, 1997). Trend OOPHE in Malaysia reflects the rising cost of using the healthcare service from time to time, and it could directly affect household finances. Figure 1 indicates the trend of OOPHE for private healthcare services from 1997 to 2015 , ranging from $73 \%$ to $80 \%$. The high percentage above shows that private healthcare is a high dependence on OOPHE to fund their operation. This high OOPHE could be a financial burden to certain people, especially to a low-income household group. Besides the high-income group, certain low-income people go for the private health sector despite higher costs due to these quality issues, mainly that of long waiting times, they pay more OOPHE (Pannarunothai \& Mills, 1997). Figure 1also indicates the total OOPHE was above $31 \%$ for the last two decades, and this percentage relative to the standards of upper-middle-income countries (31.3\%) and the Western Pacific region (29.5\%), Malaysia's OOPHE is considered high (WHO, 2016). 
INTERNATIONAL JOURNAL OF ACADEMIC RESEARCH IN BUSINESS AND SOCIAL SCIENCES Vol. 10, No. 10, 2020, E-ISSN: 2222-6990 @ 2020 HRMARS

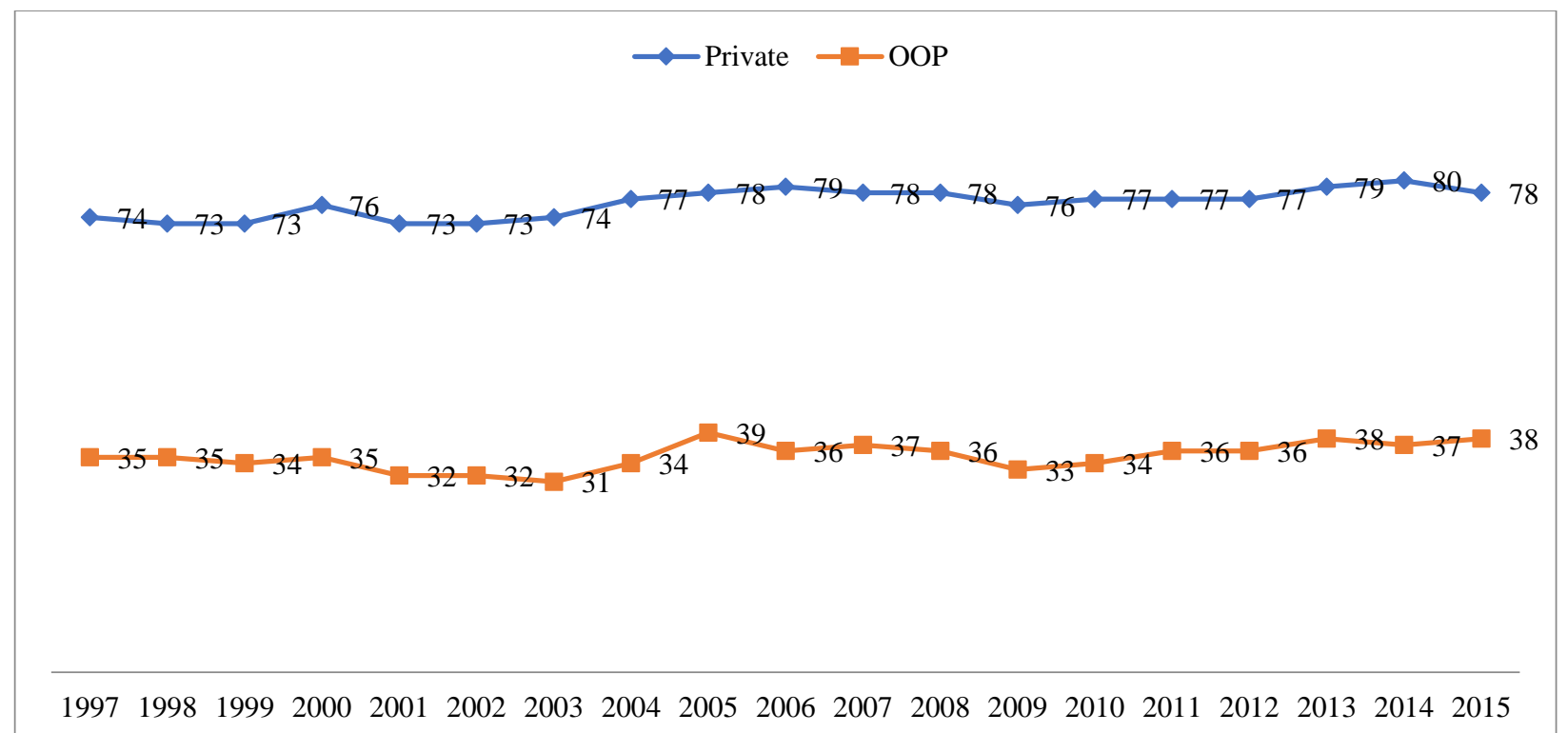

Figure 1: The private healthcare out-of-pocket and the total out-of-pocket health expenditure (OOPHE), 1997-2015 (\%).

Malaysia's OOPHE amount RM 2934 Million (1997), rising sharply to RM 19852 Million in 2015 (figure 2). This trend shows that the increasing demand for health needs among Malaysians so that they are willing to incur a certain amount of expenses for OOPHE.OOPHE is the second-largest source of funds for Malaysia and is the primary source for private healthcare (MNHA, 2016). An average OOPHE around RM397.74 per person in Malaysia (NHMS, 2015). The report stated the most affluent income group (above RM10 000) had the highest OOPHE at a mean RM2699.53 compared to the income group less than RM1000 that had a mean OOPHE amount of RM208.53. In tandem with the rising burden of OOPHE, a high degree of household economic burden is associated with OOPHE in developing countries. The finding found OOPHE increases the number of low-income households and generally disrupts people's livelihood by either pushing more families into poverty or worsening their current poverty status (Ebaidalla \& Ali, 2019).

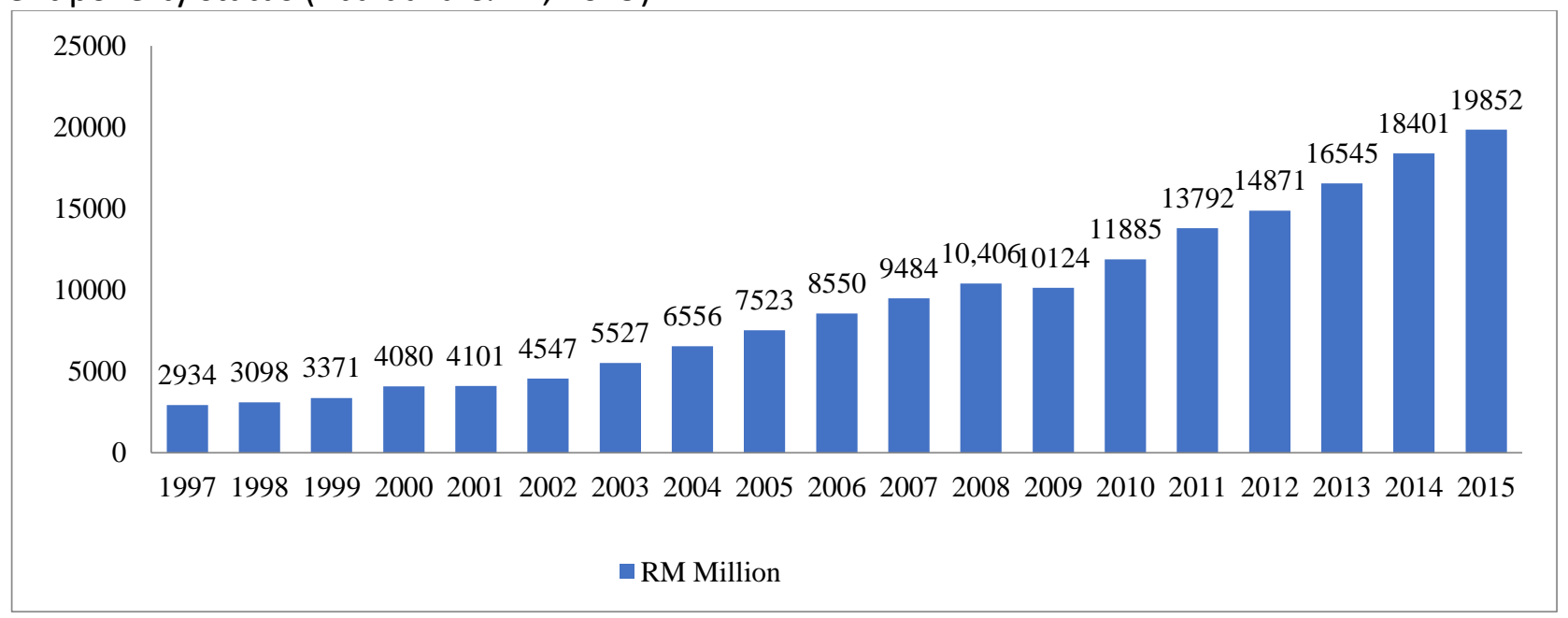

Figure 2: Out-of-pocket health expenditure (OOPHE), 1997-2015 (RM Million). 
INTERNATIONAL JOURNAL OF ACADEMIC RESEARCH IN BUSINESS AND SOCIAL SCIENCES Vol. 10, No. 10, 2020, E-ISSN: 2222-6990 @ 2020 HRMARS

It is interesting to note that Malaysia's healthcare services are heavily subsidies by the Government. However, Malaysia has a high percentage of OOPHE for a decade, maybe due to the cost of medical equipment are still borne by the patient. Even though the Malaysia Government put a lot of effort in organising the funds and assistance, some households still suffer from the medical cost burden. This research, therefore, aims to look following research objective:

- To describe the demographic factors associated with OOPHE in Malaysia.

- To determine the factors that effects pattern of OOPHE in Malaysia. Specifically, this study analyses factors affecting OOPHE incurred by the B40 group in Malaysia by using socio-economic factors, demographic characteristics, NCD, and insurance variables. It is essential to highlight this issue in determining the factors that could influence the financial conditions among the B40 group due to the high burden of health care costs incurred by households and to know which group paid and contribute the most to the OOPHE in Malaysia.

The rest of the article is structured as follows: section two presents the literature review. The methodology in section three and the results are shown in section four. Finally, section five discussion, and section six conclude.

\section{Literature Review}

The Grossman model indicates some key variables: income level, age, education status, and medical service fee relative to the demand for health services (Grossman, 1972). However, patients with a higher level of education are more likely experienced with living a healthy life, so they tend to have better health than those who do not, so healthcare service demand decreases in this case. At the same time, Grossman indicated that age is negatively linked with health demand but positively linked to health care demand. However, the medical service fee has a positive direct relationship with healthcare service demand, and income has a negative association with health demand. These critical determinants of health demand and the demand for healthcare services have been used in this study to determine the factors that influence the OOPHE among the low-income group.

As in many developing countries, OOPHE is the primary source through which health expenditure is made, and this will put the household at risk due to high OOPHE. The OOPHE jeopardizes household welfare for some people who fall into poverty due to adverse effects on income and disruption of households' material living standards (Sene \& Cisse, 2015). OOPHE burdens fall most heavily on those households with chronic disease and without employer-provided insurance or Medicaid and lowincome family (Crystal, Johnson, Harman, Sambamoorthi, \& Kumar, 2000; Kumara \& Samaratunge, 2016). Various studies have been conducted to determine the link between socio-economic, demographic factors, and OOPHE.

From the body of empirical evidence, several studies on medical costs have shown that lowincome households are more likely to suffer financial burden and to be at risk of incurring the OOPHE(Galbraith, Wong, Kim, \& Newacheck, 2005; Gross et al., 1999; Ketsche, Adams, Wallace, Kannan, \& Kannan, 2011; Kwon, Park, \& McBride, 2018). There are a limited number of studies focused on the low-income that affected by OOPHE and its factors. One of the most recent examples by (Baird, 2016) demonstrated that high spending among low-income and elderly Americans is equally common among their counterparts in many other countries. In seven of the nine countries (United States, Japan, Australia, Poland, Israel, Russia, and Switzerland), one-quarter or more of low- 
INTERNATIONAL JOURNAL OF ACADEMIC RESEARCH IN BUSINESS AND SOCIAL SCIENCES Vol. 10, No. 10, 2020, E-ISSN: 2222-6990 @ 2020 HRMARS

income citizens devoted at least five percent of their income to OOPHE; and in all nine countries, at least one-in-ten low-income citizens did.

In the Malaysia case, (Manan, Ali, Khan, \& Jafarian, 2015) study aimed to evaluate the character and commitment of Malaysian patients' towards methadone therapy in terms of their OOPHE. The finding indicated that the average OOPHE per month was RM391.30 (s.d RM337.50), which is about $35 \%$ of employed patients' monthly income. However, this survey was conducted at an urban government methadone clinic in Klang for 40 respondents. Thus, the small sample size and its small location cover are not indicative, and the result is valid only for the sample. Another study conducted in Malaysia (Baharin, Juni, \& Manaf, 2019), this previous study assesses the progressivity of OOPHE for healthcare among Malaysian households. Using cross-sectional nationally representative data derived from the Malaysian Household Expenditure Survey (HES) 2014/15 that contains 14,473 respondents, the result indicated that more than two-thirds (77\%) of Malaysian households surveyed reported to have made OOPHE. However, this study focuses on the progressivity of OOPHE only, and this study does not extend the analysis to examine the determinant of OOPHE.

(Yildirim, Yilmaz, \& Korucu, 2011) explore the determinants of the OOPHE in Ankara, Turkey, by using logistic regression analysis. The result indicated that socio-economic factors, including education and income, increase the likelihood of making OOPHE. This study obtained data from the selected hospitals in Ankara, Turkey, and a total of 500 patients have agreed to participate in the survey. Thus, the sample is not representative, and the results are valid only for the sample. Similarly, many researchers have confirmed that socio-economic factors, including working status (occupation) and income, contribute significantly to OOPHE (Amaya-Lara, 2016). The finding in line with a study by (Ebaidalla \& Ali, 2019), revealed that income and education levels significantly associate with OOPHE. However, working status (occupation) was not significantly associate with OOPHE.

This section will point out the link between demographic factors (age, strata, and gender) with OOPHE. Firstly, (Mamun, Khanam, \& Rahman, 2018) was to estimate the contributions of various determinants of OOPHE in rural Bangladesh. According to (Mamun et al., 2018), gender was a statistically significant determinant of healthcare expenditure in rural areas. The limitation of this paper indicated that the OOPHE only refer to doctor fee that paid by households. Government healthcare service choose by a household will suggest as no doctor fee while private healthcare service chooses by a household will indicate as positive doctor fee. Therefore, this indication is not an accurate measure for OOPHE. Some evidence links between demographic factors with OOPHE among Bangladesh households. A study by (Sarker et al., 2018) shows that several factors, such as age and administrative regions, were significantly associated with OOPHE, and strata were not considerably associate with OOPHE. Besides that, (Mahumud et al., 2017) also demonstrate that age, gender, place of residence (strata) are significant factors associated with OOPHE.

This segment of the literature will describe the relation between NCD with OOPHE. Research by (Pandey et al., 2018) used data from nationwide healthcare surveys conducted in India by the National Sample Survey Organization to study the determinants of OOPHE among older groups compared to a younger group. The finding demonstrated that the elderly with NCD were significantly associated with OOPHE for hospitalization than a younger population. The burden of OOPHE on 
INTERNATIONAL JOURNAL OF ACADEMIC RESEARCH IN BUSINESS AND SOCIAL SCIENCES Vol. 10, No. 10, 2020, E-ISSN: 2222-6990 @ 2020 HRMARS

hospitalization was higher for the older low-income group than the other group in 2014. Besides that, (Barasa, Maina, \& Ravishankar, 2017) explore the factors associated with the OOPHE using logistic regression analysis among Kenya households. This study revealed that NCD (hypertension, diabetes, cancer, arthritis, other) was significantly associated with OOPHE. A similar conclusion by (Aregbeshola \& Khan, 2020; Golinowska \& Tambor, 2012) in Nigeria shows that OOPHE is highest among groups with high health needs such as NCD.

It is interesting to note that health insurance had a strong relationship with OOPHE, reflecting in the below literature. Sene \& Cisse (2015) conducted a study to determine OOPHE using seemingly unrelated equations system of Tobit regressions on 5953 Senegal households. According to Sene \& Cisse (2015), health insurance is among the significant determinant of OOPHE. This result, consistent with a study on Colombian households by (Amaya-Lara, 2016) revealed that health insurance substantially influences the probability of a household having OOPHE. In particular, a study by (Minh, Phuong, Saksena, James, \& Xu, 2013) in Vietnam mentioned that households with health insurance enrollees had lower rates of OOPHE, and the statistically significant differences were found for 2004 and 2006. However, data for 2008 and 2010 showed that having health insurance was not significantly associated with lower rates of OOPHE. (Minh et al., 2013) argue that health insurance still had a modest impact on protecting people from OOPHE, and it reflects the fact that people with health insurance are still paying relatively high OOPHE.

Numerous previous studies above were conducted in a general scope or more focused on the elderly or strata. However, there are still limited studies conducted among a low-income group, especially case studies in Malaysia. Besides that, most of the findings discussed above show that the critical determinants of OOPHE are NCD, health insurance, socio-economic factors, and demographic factors associated with OOPHE. This past study was conducted in various countries, including Turkey, Sudan, Colombia, Bangladesh, India, Kenya, Nigeria, Vietnam, and Senegal. Among the long list of variables, which one is relatively the most critical indicator to OOPHE? We explore these issues in this study, thereby contributing to this knowledge gap by determining the factors that could influence the OOPHE among the B40 group (low-income group) in Malaysia.

\section{Methodology}

Data

This study used the NHMS data collected in 2015 by MOH. The first NHMS was conducted in 1986 and has since been carried out regularly. NHMS 2015 has covered the modules on health care demands, NCD (diabetes, hypertension, and hypercholesterolemia), NCD risk factors (smoking, physical inactivity, unhealthy dietary practice, alcohol consumption, and obesity), and the prevalence of other health-related problems. The nationwide survey was carried out in all thirteen States in Malaysia and three Federal territories. Structured questionnaires were used to collect data based on the scope of the study. There were two types of a questionnaire; face-to-face interview and selfadministered. This study used the single proportion formula for prevalence estimation to calculate the sample size. In total, 29,460 samples were obtained. The data suited this research, which aimed to analyze the factors related to OOPHE in Malaysia. Besides, the NHMS data also provides accurate data collection and is relevant for the current analysis. 
INTERNATIONAL JOURNAL OF ACADEMIC RESEARCH IN BUSINESS AND SOCIAL SCIENCES Vol. 10, No. 10, 2020, E-ISSN: 2222-6990 @ 2020 HRMARS

\section{Model}

Based on previous literature, we formulate the equation (1), and the model is shown below:

$\mathrm{OOP}_{i}=\beta_{0}+\beta_{1} \mathrm{SOE}_{\mathrm{i}}+\beta_{2} \mathrm{DF}_{\mathrm{i}}+\beta_{3} \mathrm{NCD}_{\mathrm{i}}+\beta_{4} \mathrm{INS}_{\mathrm{i}}+\beta_{5} B 40_{\mathrm{i}}+\beta_{6} \mathrm{~T}_{2 \mathrm{O}_{i}}+\beta_{7} \mathrm{DB}_{\mathrm{i}}+\beta_{8} \mathrm{HT}_{\mathrm{i}}+\beta_{9} \mathrm{HC}_{\mathrm{i}}+\varepsilon_{i}$ (1)

Where variable $\mathrm{OOP}_{\mathrm{i}}$ is the amount of paying OOPHE. The SOE include set socio-economic factors represented by income, education, and occupation. Besides that, DF has demographics factors such as age, gender, and strata. The other independent variables include insurance status, NCD, T20, B40, diabetes (DB), hypertension (HT), and hypercholesterolemia (HC). $\varepsilon_{i}$ is a composite error term.

The dependent variable in this study is the OOPHE. The measurement for OOPHE used in the literature refers to an amount of money household spend on healthcare service (Mahumud et al., 2017). The OOPHE includes direct medical costs such as inpatient care, outpatient care, dental care, and direct non-medical fees such as transportation, food, parking, and accommodation costs.

Following Mahumud et al. (2017), total out of pocket healthcare expenditure was derived by summing up direct medical costs and direct non-medical costs. Mahumud et al. (2017) also indicated that direct medical costs included hospital outpatient fees, medicines, admission or registration fees, physician/consultation fees, diagnostic test fees, and other associated medical supplies. In contrast, direct non-medical costs included transportation and conveyance, lodging, tips, and additional related expenses. In this study, Inpatient cares, Outpatient care, and Dental care, referring to the below description.

Inpatient care: hospitalization, overnight stay for treatment, and medication or appliances.

Outpatient care: consultation, care did not involve overnight stay for treatment, and medication or appliances.

Dental care: dental check-up, treatment for toothache or sensitive tooth, swollen gums, loss of teeth, denture problems, irregularly aligned teeth, mouth ulcers, and jaw pain.

The selection of variables in equation (1) is based on a previous study. The expected result of income and NCD is significant-associate with OOPHE, whereas gender is not significantly associated with OOPHE. A similar analysis performed by Koris et al. (2019) includes income, gender, chronic disease (NCD), and some other variables to analyze the determinant of healthcare costs among the elderly. Following a previous study, we include income, NCD, disease type, and gender in this analysis. Income level is classified into three groups, which are B40 (income less than RM4849.00), M40 (income from RM4850.00 to RM10959.00), and T20 (income above RM10959.00). This study also includes the log income to compare the result with dummy income. NCD refers to chronic disease incur by households, proxy by whether or not a household has non-communicable diseases. Besides that, the study also includes diabetes mellitus, hypertension, or hypercholesterolemia are the dummy variable. Gender refers to male or female.

The expected result of the household's age and education is significantly associated with OOPHE, whereas the occupation is expected to significant negative associated with OOPHE. Consistent with a past study (Mahumud et al., 2017), OOPHE was regressed into an independent variable such as age, education, and working status. Based on the literature, age is grouped into four categories: 0 to 19 years old, 20 to 39 years old, 40 to 64 years old, and above 65 years old. Simultaneously, education levels consist of non-formal, primary, secondary, tertiary, or unclassified. Meanwhile, occupation 
INTERNATIONAL JOURNAL OF ACADEMIC RESEARCH IN BUSINESS AND SOCIAL SCIENCES Vol. 10 , No. 10, 2020, E-ISSN: 2222-6990 @ 2020 HRMARS

status is specified as a government employee, private employee, self-employed, unpaid worker, retire, or other.

Apart from the above variables, the expected result for the strata variable is significant with OOPHE. The expected result is in line with a study by (Sene \& Cisse, 2015) that households in rural and urban Senegal were significantly associated with OOPHE. The current research adopted a strata class that is specified as rural or urban. Next, the expected result for insurance is significant influences the OOPHE. The finding also reported by (Kwon, Park \& McBride, 2018) that assess the effects of health insurance and poverty on OOPHE among low-income late middle-aged adults. Finally, insurance status includes employer-sponsored insurance or private personal or health insurance plans with no indication of yes or no scores.

\section{Statistical Analysis}

Data were analyzed using STATA version 15 software. Descriptive statistics are used to analyze the study sample's individual and household characteristics in the form of frequency tables, straightforward percentages, mean and standard deviation. Next analysis using Ordinary Least Square (OLS) regression to explore the factors linked to OOPHE. Income and total OOPHE variables in the regressions are logged when expressed in Ringgit Malaysia terms to reduce skewness. Zero values of the regressions' variables are turning out to be missing value, and it is set to zero to retain those families with zero expenditures in the regressions. This analysis uses the independent variable including strata, gender, age, log income, education level, occupation status, B40 income group, M40 income group, T20 income group, insurance status, NCD, Diabetes, Hypertension, and Hypercholesterolemia.

\section{Result}

\section{Descriptive Analysis}

This study identified 21,395 respondents categorized as a low-income group (B40) and represent $72.62 \%$ of the total income group. While the highest-income group (T20), representing5.50\% (1620 respondents). The table1 below demonstrated that age below 19 representing 34.98\% (10306 respondents) compared to the older group age 40 to 64 years old representing $29.16 \%$ (8590 respondents) and above 65 years old representing $8.31 \%$ ( 2449 respondents). This study presents the socio-economic, demographic factors, insurance status, and disease type of participants ( $n=29460)$ in Table 1. The majority of the participants are female, urban, and secondary education, private employee, have no insurance, and have non-communicable diseases. Overall, families spent an average of RM110.27 on total OOPHE, and the mean family income is RM4090.13. 
INTERNATIONAL JOURNAL OF ACADEMIC RESEARCH IN BUSINESS AND SOCIAL SCIENCES Vol. 10, No. 10, 2020, E-ISSN: 2222-6990 @ 2020 HRMARS

Table-1. Descriptive analysis.

\begin{tabular}{|c|c|c|c|}
\hline Variables & $n$ & $\%$ & Mean (S.D) \\
\hline $\begin{array}{l}\text { Age } \\
\begin{array}{l}0-19 \\
20-39 \\
40-64 \\
>65\end{array}\end{array}$ & $\begin{array}{c}10306 \\
8115 \\
8590 \\
2449 \\
\end{array}$ & $\begin{array}{c}34.98 \\
27.55 \\
29.16 \\
8.31 \\
\end{array}$ & $2.11(0.981)$ \\
\hline $\begin{array}{c}\text { Strata } \\
\text { Urban } \\
\text { Rural }\end{array}$ & $\begin{array}{l}16880 \\
12580\end{array}$ & $\begin{array}{l}57.30 \\
42.70\end{array}$ & $1.43(0.495)$ \\
\hline $\begin{array}{c}\text { Gender } \\
\text { Male } \\
\text { Female }\end{array}$ & $\begin{array}{l}14225 \\
15235 \\
\end{array}$ & $\begin{array}{l}48.29 \\
51.71 \\
\end{array}$ & $1.52(0.500)$ \\
\hline Income & & & $4090.13(5413.240)$ \\
\hline $\begin{array}{l}\text { Education } \\
\text { No formal education } \\
\text { Primary } \\
\text { Secondary } \\
\text { Tertiary } \\
\text { Unclassified }\end{array}$ & $\begin{array}{c}1995 \\
8611 \\
10354 \\
4403 \\
4097 \\
\end{array}$ & $\begin{array}{c}6.77 \\
29.23 \\
35.15 \\
14.95 \\
13.91 \\
\end{array}$ & $3.00(1.126)$ \\
\hline $\begin{array}{l}\text { Occupation } \\
\text { Government } \\
\text { employee } \\
\text { Private employee } \\
\text { Self-employed } \\
\text { Unpaid worker } \\
\text { Retired } \\
\text { Other }\end{array}$ & $\begin{array}{c}2195 \\
6206 \\
3892 \\
3352 \\
786 \\
13,029\end{array}$ & $\begin{array}{c}7.45 \\
21.07 \\
13.21 \\
11.38 \\
2.67 \\
44.23\end{array}$ & $4.13(1.850)$ \\
\hline
\end{tabular}


INTERNATIONAL JOURNAL OF ACADEMIC RESEARCH IN BUSINESS AND SOCIAL SCIENCES Vol. 10, No. 10, 2020, E-ISSN: 2222-6990 @ 2020 HRMARS

\begin{tabular}{|c|c|c|c|}
\hline $\begin{array}{l}\text { B40 (<RM 4849) } \\
\text { Yes } \\
\text { No }\end{array}$ & $\begin{array}{c}21,395 \\
8,065\end{array}$ & $\begin{array}{l}72.62 \\
27.38\end{array}$ & $1.27(0.446)$ \\
\hline $\begin{array}{l}\text { M40 (RM } 4850-\text { RM } \\
\text { 10959) } \\
\text { Yes } \\
\text { No }\end{array}$ & $\begin{array}{c}6,445 \\
23,015\end{array}$ & $\begin{array}{l}21.88 \\
78.12\end{array}$ & $1.78(0.413)$ \\
\hline $\begin{array}{l}\text { T20 (> RM 10959) } \\
\text { Yes } \\
\text { No }\end{array}$ & $\begin{array}{c}1,620 \\
27,840 \\
\end{array}$ & $\begin{array}{c}5.50 \\
94.50 \\
\end{array}$ & $1.95(0.228)$ \\
\hline $\begin{array}{l}\text { NCD } \\
\text { Yes } \\
\text { No }\end{array}$ & $\begin{array}{c}13569 \\
6366\end{array}$ & $\begin{array}{l}68.07 \\
31.93 \\
\end{array}$ & $1.86(0.875)$ \\
\hline $\begin{array}{l}\text { Diabetes } \\
\text { Yes } \\
\text { No }\end{array}$ & $\begin{array}{c}4229 \\
15706\end{array}$ & $\begin{array}{l}21.21 \\
78.79 \\
\end{array}$ & $2.18(0.659)$ \\
\hline $\begin{array}{l}\text { Hypertension } \\
\text { Yes } \\
\text { No }\end{array}$ & $\begin{array}{c}7225 \\
12,710\end{array}$ & $\begin{array}{l}24.52 \\
43.14 \\
\end{array}$ & $2.08(0.750)$ \\
\hline $\begin{array}{l}\text { Hypercholesterolemia } \\
\text { Yes } \\
\text { No }\end{array}$ & $\begin{array}{c}10514 \\
9421\end{array}$ & $\begin{array}{l}35.69 \\
31.98 \\
\end{array}$ & $1.97(0.824)$ \\
\hline $\begin{array}{l}\text { Insurance } \\
\text { Yes } \\
\text { No }\end{array}$ & $\begin{array}{c}6803 \\
22657\end{array}$ & $\begin{array}{l}23.09 \\
76.91\end{array}$ & $1.77(0.421)$ \\
\hline Total OOP & & & $0.27(2745.27$ \\
\hline
\end{tabular}

\section{OLS Regression Result}

Next, the OLS regression result is described in table 2. All model in this regression refers to the equation (1) above. The regressions are tested for multicollinearity; the test was necessary to establish estimation accuracy as the model involved a lengthy list of independent variables (O'Brien, 2007). Variance inflation factor (VIF) is calculated to determine the probability of multicollinearity. (Pallant, 2011) stated a VIF value of more than ten indicates a multicollinearity problem. In the model, the VIF value ranged below six. Therefore, the model had no multicollinearity problem.

The demographic factors include age, strata area, and gender. In terms of households' age, the age group consists of four categories, including below 19 years old, 20 to 39 years old, 40 to 64 years old, and above 65 years old. Age below 19 years old is the reference group. The age group results are not significant for all age groups (model 1,2 , and 5 ), and positive significant at $5 \%$ and $10 \%$ for model 3,4 , and 6 . Next, strata (urban area) are positive significant at $1 \%$ for model 1,3 , and 4 with OOPHE, while positive significant at $10 \%$ level for model 2 . Other model shows no significant associated OOPHE for strata (urban). Besides that, the result demonstrated that gender (female) positively 
INTERNATIONAL JOURNAL OF ACADEMIC RESEARCH IN BUSINESS AND SOCIAL SCIENCES Vol. 10, No. 10, 2020, E-ISSN: 2222-6990 @ 2020 HRMARS

significant at $1 \%$ level with OOPHE for all model, which show that female spend more on OOPHE compared to male.

Under socio-economic factors, income is strongly positive significant at a $1 \%$ level with OOPHE for all models. In line with dummy variables for income and the result show, B40 and T20 are strongly significant with OOPHE. The B40 (low-income) spend less on OOPHE compared to another household income group vice versa for the T20 group. The tertiary education is positive significant with OOPHE from model 1 to model 6 . As expected, the tertiary education is strongly significant (at 1\%) with a high coefficient, which showed that for each tertiary education unit, the OOPHE would increase by 0.7 units compared to other education levels. While no formal education is not significant in all models, primary and secondary education levels are significant at $5 \%$ and $1 \%$ level for model 1 , model 2 , and model 5 . For the occupation variable, private employees and self-employed are negatively significant with OOPHE for all models than other occupations. A private employee is significant at a $1 \%$ level for all models, and self-employed are significant at $1 \%, 5 \%$, and $10 \%$ level for all models. While unpaid workers and retire are positively significant at $5 \%$ and $10 \%$ level with OOPHE for all models than other occupations. Lastly, a government worker is not significant with OOPHE. This result indicated that private employee and self-employed spend less on OOPHE compared to unpaid work and retire.

The NCD result in model 3 and 6 demonstrated that positive significant at a $1 \%$ level is associated with OOPHE. Based on the coefficients, the result indicated that the household with NCD spends more on OOPHE compared to without NCD. This result also indicated that model 4 demonstrated that diabetes is strongly significant with OOPHE compared to a household without diabetes. Besides that, from table 2 show hypertension and hypercholesterolemia are not significantly associated with OOPHE. However, the finding indicated that insurance status strongly negatively significant with OOPHE for Model 5 and 6 at a 1\% level. The result revealed that household with insurance spends less on OOPHE compared to the household without insurance.

Overall, the results of the Ordinary Least Square (OLS) regression can be seen in table 2 and this analysis to identify the relationship between OOPHE and independent variables. The analysis showsa simple linear regression was calculated to predict OOPHE based on factors associated with OOPHE. A significant regression equation was found $\left(F(15,29444)=44.24, p<.000, R^{2}=0.0220\right)$ for model 1 , $\left(\mathrm{F}(15,29444)=44.24, p<.000, R^{2}=0.0220\right)$ for model $1,\left(\mathrm{~F}(17,29442)=45.19, p<.000, R^{2}=0.0254\right)$ for model 2, $\left(\mathrm{F}(16,19918)=37.47, p<.000, R^{2}=0.0292\right)$ for model 3 , $(\mathrm{F}(18,19916)=34.16, p<$ $\left..000, R^{2}=0.0299\right)$ for model $4,\left(\mathrm{~F}(16,29443)=58.31, p<.000, R^{2}=0.0307\right)$ for model 5 and $(\mathrm{F}(17$, 19917) $=45.48, p<.000, R^{2}=0.0374$ ) for model 6 . 
INTERNATIONAL JOURNAL OF ACADEMIC RESEARCH IN BUSINESS AND SOCIAL SCIENCES Vol. 10, No. 10, 2020, E-ISSN: 2222-6990 @ 2020 HRMARS

Table 2: Factors associated with out-of-pocket health expenditure (OOPHE).

\begin{tabular}{|c|c|c|c|c|c|c|}
\hline & 1 & 2 & 3 & 4 & 5 & 6 \\
\hline \multicolumn{7}{|l|}{$\begin{array}{l}\text { Age(0-19: } \\
\text { reference) }\end{array}$} \\
\hline $20-39$ & $\begin{array}{l}-0.0122282 \\
(0.0486788)\end{array}$ & $\begin{array}{c}0.0068366 \\
(0.0486363)\end{array}$ & $\begin{array}{c}0.1896506 \\
(0.0830777) \\
* *\end{array}$ & $\begin{array}{c}0.1929976 \\
(0.0830046) \\
* *\end{array}$ & $\begin{array}{c}0.0005254 \\
(0.0484696)\end{array}$ & $\begin{array}{c}0.1507472 \\
(0.0827848) \\
*\end{array}$ \\
\hline $40-64$ & $\begin{array}{c}-.0284027 \\
(0.0461956)\end{array}$ & $\begin{array}{c}-0.026817 \\
(0.0461215)\end{array}$ & $\begin{array}{c}0.1624513 \\
(0.0847311) \\
*\end{array}$ & $\begin{array}{c}0.154659 \\
(0.0850282) \\
*\end{array}$ & $\begin{array}{l}-0.0260233 \\
(0.0459913)\end{array}$ & $\begin{array}{c}0.1073655 \\
(0.0844837)\end{array}$ \\
\hline$>65$ & $\begin{array}{l}-0.0071784 \\
(0.0522864)\end{array}$ & $\begin{array}{c}-0.0183242 \\
(0.0522112)\end{array}$ & $\begin{array}{c}0.2411028 \\
(0.0953664) \\
* *\end{array}$ & $\begin{array}{c}0.2214779 \\
(0.0962787) \\
* *\end{array}$ & $\begin{array}{c}0.0269171 \\
(0.0520972)\end{array}$ & $\begin{array}{c}0.2053578 \\
(0.0950078) \\
* *\end{array}$ \\
\hline $\begin{array}{l}\text { Strata } \\
\text { (urban) }\end{array}$ & $\begin{array}{c}0.0841347 \\
(0.0243914) \\
* * *\end{array}$ & $\begin{array}{c}0.0455444 \\
(0.0246944) \\
*\end{array}$ & $\begin{array}{c}0.0874886 \\
(0.0318362) \\
* * *\end{array}$ & $\begin{array}{c}0.0863001 \\
(0.0318401) \\
* * *\end{array}$ & $\begin{array}{c}0.029586 \\
(0.0245148)\end{array}$ & $\begin{array}{c}0.0369914 \\
(0.0319409)\end{array}$ \\
\hline $\begin{array}{l}\text { Gender(fe } \\
\text { male) }\end{array}$ & $\begin{array}{c}0.2037475 \\
(0.0253732) \\
* * *\end{array}$ & $\begin{array}{c}0.2024303 \\
(0.0253307) \\
* * *\end{array}$ & $\begin{array}{c}0.2951741 \\
(0.0341403) \\
* * *\end{array}$ & $\begin{array}{c}0.2983332 \\
(0.0342315) \\
* * *\end{array}$ & $\begin{array}{c}0.2144334 \\
(0.0252694) \\
* * *\end{array}$ & $\begin{array}{c}0.3043207 \\
(0.034005) \\
* * *\end{array}$ \\
\hline $\begin{array}{l}\text { Log } \\
\text { Income }\end{array}$ & $\begin{array}{c}0.0475458 \\
(0.0061843) \\
* * *\end{array}$ & $\begin{array}{c}0.0215312 \\
(0.0067906) \\
* * *\end{array}$ & $\begin{array}{c}0.0466245 \\
(0.0081408) \\
* * *\end{array}$ & $\begin{array}{c}0.0462765 \\
(0.0081396) \\
* * *\end{array}$ & $\begin{array}{c}0.0382766 \\
(0.0061834) \\
* * *\end{array}$ & $\begin{array}{c}0.0395217 \\
(0.0081253) \\
* * *\end{array}$ \\
\hline \multicolumn{7}{|l|}{$\begin{array}{l}\text { Education } \\
\text { (unclassifie } \\
\text { d: } \\
\text { reference) }\end{array}$} \\
\hline $\begin{array}{l}\text { No formal } \\
\text { education }\end{array}$ & $\begin{array}{c}-0.0225994 \\
(0.0592278) \\
\end{array}$ & $\begin{array}{c}-0.0201413 \\
(0.0591331) \\
\end{array}$ & $\begin{array}{c}-0.147148 \\
(0.1520039) \\
\end{array}$ & $\begin{array}{c}-0.1474809 \\
(0.1519599) \\
\end{array}$ & $\begin{array}{l}0.0006604 \\
(0.058983) \\
\end{array}$ & $\begin{array}{c}-0.1234393 \\
(0.1513798)\end{array}$ \\
\hline Primary & $\begin{array}{c}0.0954921 \\
(0.0413841) \\
* *\end{array}$ & $\begin{array}{c}0.0985091 \\
(0.0413181) \\
* *\end{array}$ & $\begin{array}{l}-0.0083434 \\
(0.1428341)\end{array}$ & $\begin{array}{c}-0.0066634( \\
0.1428102)\end{array}$ & $\begin{array}{c}0.1089691 \\
(0.0412092) \\
* * *\end{array}$ & $\begin{array}{l}0.0109159 \\
(0.142245)\end{array}$ \\
\hline Secondary & $\begin{array}{c}0.1739928 \\
(0.0450471) \\
* * *\end{array}$ & $\begin{array}{c}0.1726119 \\
(0.0449709) \\
* * *\end{array}$ & $\begin{array}{c}0.1777854 \\
(0.1405159)\end{array}$ & $\begin{array}{c}0.1829171 \\
(0.1404891)\end{array}$ & $\begin{array}{c}0.1697522 \\
(0.0448484) \\
* * *\end{array}$ & $\begin{array}{c}0.1559976 \\
(0.1399388)\end{array}$ \\
\hline Tertiary & $\begin{array}{c}0.7434731 \\
(0.0557715) \\
* * *\end{array}$ & $\begin{array}{c}0.6697919 \\
(0.056161) \\
* * *\end{array}$ & $\begin{array}{c}0.7215485 \\
(0.1432831) \\
* * *\end{array}$ & $\begin{array}{c}0.72998 \\
(0.1432622) \\
* * *\end{array}$ & $\begin{array}{c}0.6581209 \\
(0.055773) \\
* * *\end{array}$ & $\begin{array}{c}0.6198094 \\
(0.1428995) \\
* * *\end{array}$ \\
\hline \multicolumn{7}{|l|}{$\begin{array}{l}\text { Occupatio } \\
\mathrm{n} \text { (other: } \\
\text { reference) }\end{array}$} \\
\hline $\begin{array}{l}\text { Governme } \\
\text { nt } \\
\text { employee }\end{array}$ & $\begin{array}{l}-0.0107776 \\
(0.0609146)\end{array}$ & $\begin{array}{c}-0.0178611 \\
(0.0608776)\end{array}$ & $\begin{array}{c}0.0092314 \\
(0.0664993)\end{array}$ & $\begin{array}{l}0.0229383 \\
(0.066522)\end{array}$ & $\begin{array}{l}-0.0771702 \\
(0.0607827)\end{array}$ & $\begin{array}{c}-0.0697602 \\
(0.0665004)\end{array}$ \\
\hline
\end{tabular}


INTERNATIONAL JOURNAL OF ACADEMIC RESEARCH IN BUSINESS AND SOCIAL SCIENCES Vol. 10, No. 10, 2020, E-ISSN: 2222-6990 @ 2020 HRMARS

\begin{tabular}{|c|c|c|c|c|c|c|}
\hline $\begin{array}{l}\text { Private } \\
\text { employee }\end{array}$ & $\begin{array}{c}-0.224366 \\
(0.0462674) \\
* * *\end{array}$ & $\begin{array}{c}-0.2141963 \\
(0.0461998) \\
* * *\end{array}$ & $\begin{array}{c}-0.1663313 \\
(0.0525166) \\
* * *\end{array}$ & $\begin{array}{c}-0.1510362 \\
(0.0526375) \\
* * *\end{array}$ & $\begin{array}{c}-0.2993356 \\
(0.0462935) \\
* * *\end{array}$ & $\begin{array}{c}-0.2602281 \\
(0.052795) \\
* * *\end{array}$ \\
\hline $\begin{array}{l}\text { Self- } \\
\text { employed }\end{array}$ & $\begin{array}{c}-0.1776311 \\
(0.049212) \\
* * *\end{array}$ & $\begin{array}{c}-0.1694267 \\
(0.0491368) \\
* * *\end{array}$ & $\begin{array}{c}-0.1134923 \\
(0.055113) \\
* *\end{array}$ & $\begin{array}{c}-0.0995353 \\
(0.0552046) \\
*\end{array}$ & $\begin{array}{c}-0.1825836 \\
(0.0489951) \\
* * *\end{array}$ & $\begin{array}{c}-0.1328338 \\
(0.0549029) \\
* *\end{array}$ \\
\hline $\begin{array}{l}\text { Unpaid } \\
\text { worker }\end{array}$ & $\begin{array}{c}0.1133051 \\
(0.05132) * *\end{array}$ & $\begin{array}{c}0.1251321 \\
(0.0512472) \\
* *\end{array}$ & $\begin{array}{c}0.1043496 \\
(0.0566052) \\
*\end{array}$ & $\begin{array}{c}0.109733 \\
(0.0566008) \\
*\end{array}$ & $\begin{array}{c}0.1143034 \\
(0.0510928) \\
* *\end{array}$ & $\begin{array}{c}0.0941665 \\
(0.0563741) \\
*\end{array}$ \\
\hline Retiree & $\begin{array}{c}0.1692678 \\
(0.0816527) \\
* *\end{array}$ & $\begin{array}{c}0.1898114 \\
(0.0815394) \\
* *\end{array}$ & $\begin{array}{c}0.1905247 \\
(0.0877656) \\
* *\end{array}$ & $\begin{array}{c}0.1835093 \\
(0.0877589) \\
*\end{array}$ & $\begin{array}{c}0.1894704 \\
(0.0813007) \\
* *\end{array}$ & $\begin{array}{c}0.2054555 \\
(0.0874064) \\
* *\end{array}$ \\
\hline B40 & & $\begin{array}{c}-0.1794563 \\
(0.0319489) \\
* * *\end{array}$ & & & & \\
\hline T20 & & $\begin{array}{c}0.3654619 \\
(0.0567648) \\
* * *\end{array}$ & & & & \\
\hline NCD & & & $\begin{array}{c}0.1097391 \\
(0.0353575) \\
* * *\end{array}$ & & & $\begin{array}{c}0.1133788 \\
(0.0352109) \\
* * *\end{array}$ \\
\hline Diabetes & & & & $\begin{array}{c}0.1746872 \\
(0.0394016) \\
* * *\end{array}$ & & \\
\hline $\begin{array}{l}\text { Hypertensi } \\
\text { on }\end{array}$ & & & & $\begin{array}{c}0.048768 \\
(0.0358029)\end{array}$ & & \\
\hline $\begin{array}{l}\text { Hyperchol } \\
\text { esterolemi } \\
\text { a }\end{array}$ & & & & $\begin{array}{l}0.0039433 \\
(0.032174)\end{array}$ & & \\
\hline Insurance & & & & & $\begin{array}{c}-0.4837386 \\
(0.0298006) \\
* * *\end{array}$ & $\begin{array}{c}-0.4919969 \\
(0.0379013) \\
* * *\end{array}$ \\
\hline & $\begin{array}{c}F(15,29444) \\
=44.24 \\
p=0.0000\end{array}$ & $\begin{array}{c}F(17,29442) \\
=45.19 \\
p=0.0000\end{array}$ & $\begin{array}{c}F(16,19918) \\
=\quad 37.47 \\
p=0.0000\end{array}$ & $\begin{array}{c}F(18,19916) \\
=\quad 34.16 \\
p=0.0000\end{array}$ & $\begin{array}{c}F(16,29443) \\
=\quad 58.31 \\
p=0.0000\end{array}$ & $\begin{array}{c}F(17,19917) \\
=\quad 45.48 \\
p=0.0000\end{array}$ \\
\hline R-squared & 0.0220 & 0.0254 & 0.0292 & 0.0299 & 0.0307 & 0.0374 \\
\hline $\begin{array}{l}\text { Adj R- } \\
\text { squared }\end{array}$ & 0.0215 & 0.0249 & 0.0284 & 0.0291 & 0.0302 & 0.0365 \\
\hline Root MSE & 2.0204 & 2.017 & 2.1436 & 2.1429 & 2.0115 & 2.1346 \\
\hline
\end{tabular}


INTERNATIONAL JOURNAL OF ACADEMIC RESEARCH IN BUSINESS AND SOCIAL SCIENCES Vol. 10, No. 10, 2020, E-ISSN: 2222-6990 @ 2020 HRMARS

\section{Robustness Check}

Robustness check might be considered a situation where the researcher investigates how these estimates of regression coefficient behave when regression specification is modified in some way, usually by removing or adding the independent variable (Lu \& White, 2014). The coefficient does not alter much is taken as indications that they are robust (Lu \& White, 2014). Table 3 shows the results of the OLS regression analysis for each one of the independent variables. The reference category of some independent variables is changed to test the model's robustness to explore their effect. The result suggested that the findings are consistent in direction and significance and do not change much. The model indicates that variables, such as strata, gender, household income, education, private employee, self-employed, unpaid worker, retire, and NCD, significantly explain the likelihood of a household having OOPHE.

Table 3: Regression analysis result.

\begin{tabular}{|c|c|c|}
\hline & Coef. & Std. Err. \\
\hline \multicolumn{3}{|l|}{ Age(>65: reference) } \\
\hline $0-19$ & $(-0.213091) * *$ & 0.0963763 \\
\hline $20-39$ & $(-0.0259188)$ & 0.0643090 \\
\hline $40-64$ & $(-0.0675433)$ & 0.0571255 \\
\hline Strata (rural) & $(-0.0856899) * * *$ & 0.0318397 \\
\hline Gender(male) & $(-0.3003044) * * *$ & 0.0342455 \\
\hline Log Income & $(0.0462282) * * *$ & 0.0081391 \\
\hline \multicolumn{3}{|c|}{$\begin{array}{l}\text { Education(no formal education: } \\
\text { reference) }\end{array}$} \\
\hline Primary & $(0.141654) * *$ & 0.0669652 \\
\hline Secondary & $(0.332195) * * *$ & 0.0677464 \\
\hline Tertiary & $(0.8794725) * * *$ & 0.0748607 \\
\hline Unclassified & $(0.1498679)$ & 0.1519556 \\
\hline \multicolumn{3}{|c|}{$\begin{array}{l}\text { Occupation (government employee: } \\
\text { reference) }\end{array}$} \\
\hline Private employee & $(-0.1725861) * * *$ & 0.0553356 \\
\hline Self-employed & $(-0.1212495)^{* *}$ & 0.0608312 \\
\hline Unpaid worker & $(0.0886414)$ & 0.0655245 \\
\hline Retiree & $(0.1615501)^{*}$ & 0.0942168 \\
\hline Other & $(-0.0205281)$ & 0.0665302 \\
\hline \multirow[t]{2}{*}{$\mathrm{NCD}$ (no) } & $(-0.1089191)^{* * *}$ & 0.0580584 \\
\hline & $\begin{array}{c}\mathrm{F}(19,19915)=32.55 \\
P=0.0000\end{array}$ & \\
\hline R-squared & 0.0301 & \\
\hline Adj R-squared & 0.0292 & \\
\hline Root MSE & 2.1428 & \\
\hline
\end{tabular}


INTERNATIONAL JOURNAL OF ACADEMIC RESEARCH IN BUSINESS AND SOCIAL SCIENCES Vol. 10, No. 10, 2020, E-ISSN: 2222-6990 @ 2020 HRMARS

\section{Discussion}

NCD, household socio-economic status, demographic characteristics, and the health insurance status sure will change the ratio of health expenses for households and significant risk factors for OOPHE. The findings based on the NHMS2015 data convey a similar message indicating that gender (female), household income, tertiary education, occupation status, NCD, and insurance status are significantly associated with OOPHE. The result revealed that the female gender likely to spend more on OOPHE compared to the male gender. Females have higher healthcare consumption due to natural biological such as birth control, pregnancy, and childbirth, which mostly explained the higher burden for females. Besides, females also usually have caregivers' roles in households and earn less on average; thus, females might be longer inactive economically. This result support by (Aregbeshola \& Khan, 2020; Kočiš Krůtilová \& Doubková, 2018) revealed that female is a significant predictor of a higher OOPHE compared to male. In term of income, the result shows that the highest-income group (T20) spend more on OOPHE compared to lower-income group (B40). It can be concluded that the highestincome in Malaysia dominates the percentage of OOPHE compared to the lower-income group. The result shows that many highest-income people spend more money to get treatment at health care facilities than the lower-income. The finding in line with (Baharin et al., 2019; Yu, Whynes, \& Sach, 2006), both studies revealed that the Malaysian's higher-income group has the largest ability to pay for OOPHE and the leading contributor.

Apart from income level issues, this study also looks at the education factor. The result of this study discovered that tertiary education spends more on OOPHE compared to other education levels. The result explained that a highly educated household is more willing to go to better health services for their families. A household with a higher education level having higher earning (McNabb \& Said, 2013; Yunus \& Said, 2016), and households with higher earning afford to seek high-quality healthcare services. The result support by (Ebaidalla \& Ali, 2019) demonstrated that university education is positive and statistically significant with OOPHE. The study result indicated that private employees and self-employed spend less on OOPHE than unpaid work and retire. A household with a stable income who manages to purchase personal insurance or covers by employer-provided insurance is likely less to pay OOPHE than an unpaid work and retire who may not cover by insurance have to pay OOPHE. The finding in line with a past study by (Sarker et al., 2018), indicated that the household's working status was negative significantly associated with OOPHE, and working households spent less than unemployed households.

Another interesting finding of this study is households with NCD spend more on OOPHE compared to without NCD, and the analysis for diabetes has the same result. The result revealed that households with NCD are likely to incur OOPHE due to long-term treatment and an extended stay at the hospital, which leads to an increase in medical bills, transportation, and accommodation cost. A previous study in line with this result revealed that the OOPHE is higher for a household with NCD (Aregbeshola \& Khan, 2020; Pandey et al., 2018) and diabetes (Arsenijevic, Pavlova, Rechel, \& Groot, 2016). Next, the result revealed that households with insurance spend less on OOPHE than the household without insurance. Health insurance programs are designed to provide financial relief to enrollees by subsidizing payments for health services and prescribed medicines. The finding confirmed that insurance coverage would lead to lower OOPHE. However, the result contradicts (You 
INTERNATIONAL JOURNAL OF ACADEMIC RESEARCH IN BUSINESS AND SOCIAL SCIENCES Vol. 10, No. 10, 2020, E-ISSN: 2222-6990 ๑ 2020 HRMARS

\& Kobayashi, 2011) but supported by (Kwon et al., 2018) stated that households with no insurance had higher OOPHE.

\section{Conclusion}

This study is examining the factors associated with OOPHE among the low-income group in Malaysia. Focusing on the OOPHE that includes direct medical cost and direct non-medical cost, this study found the argument that several key factors influence OOPHE. Results show that the household income, tertiary education, occupation status, female gender, NCD, and insurance status are all key in affecting OOPHE.

The finding shows that the low-income group in Malaysia spend less on OOPHE than the highestincome group. This situation indicates that Malaysia's Government provides a range of inexpensive healthcare for those in need. In particular, direct OOPHE in Malaysia is almost entirely for the purchase of private healthcare services. In general, private healthcare is often obtained and consumed by the highest-income group and reflects on the OOPHE distribution most among the highest-income group. The result would never surprising considering the highest-income group is more likely to afford those services. The results of this research support the idea that by achieving Universal Health Coverage (UHC) and enhanced primary healthcare programs, Malaysia's Government committed to providing top-quality healthcare. In the future, through UHC, all household's income groups would have more access to affordable healthcare without having to face financial pressure due to NCD and lack of insurance.

This study shows that households with healthcare costs will experience a financial burden, especially OOPHE. To better understand the key reasons for OOPHE, it would be necessary to protect a household with chronic conditions, particularly from financial burden. The result also suggested that insurance schemes, personal health insurance, or employer-provided insurance tend to lessen OOPHE. Besides that, the penetration of life insurance was 3.08\% of GDP, below the global average of $3.69 \%$. These results clearly show that many Malaysian households substantially do not have health insurance (Redzuan, Yakob, \& Isa, 2016). This situation highlights the need for experts and decision-makers to track and intensively analyze the impact of ongoing health insurance reform in Malaysia.

Besides that, this study suggests that retire raises the likelihood of incurring OOPHE. This relationship was in line with the Grossman Model, which stated that age and income positively affected the demand for healthcare services. But the result for education indicated that higher education raises the likelihood of incurring OOPHE; contradict Grossman model stated that a higher level of education suggests demand for healthcare services would decrease. Besides these critical factors, this analysis also shows gender (female) of household, unpaid worker, and NCD raises the likelihood of incurring OOPHE. The result for a private employee, self-employed, and insurance status is spending less on OOPHE. The findings should be robust and consistent after this analysis uses OLS regression, one of the fundamental techniques used to analyze data. This study also carries out the robustness check on how these regression coefficient estimates behave when regression specification is modified. The coefficient does not change much can be considered robust (Lu \& White, 2014).

These findings have significant implications for the understanding of how socio-economic and demographic factors are associated with OOPHE. By looking at factors like age, gender, strata, 
INTERNATIONAL JOURNAL OF ACADEMIC RESEARCH IN BUSINESS AND SOCIAL SCIENCES Vol. 10, No. 10, 2020, E-ISSN: 2222-6990 @ 2020 HRMARS

income, and occupations, this study identified characteristics of household characteristics that contribute to the pattern of the contribution of OPPHE. Varies between men and women is essential to consider the effects of demographic characteristics when seeking an explanation of contribution patterns. This study found that the critical finding is that the highest-income group (T20) in Malaysia spend more on OOPHE than the lower-income group (B40). This result reflects that the T20 group is the major spender for OOPHE in Malaysia compared to the B40 group. This situation indicates that private health care services in Malaysia are considered affordable to the T20 group. These groups are willing to spend on health care rather than facing long queues and crowded public health care facilities. This paper contributes to recent historiographical debates concerning nationwide survey for all states and federal territories in Malaysia. The current data highlight the importance of comprehensive and more reliable results.

\section{References}

Amaya-Lara, J. L. (2016). Catastrophic expenditure due to out-of-pocket health payments and its determinants in Colombian households. International Journal for Equity in Health, 15(1), 1-11. https://doi.org/10.1186/s12939-016-0472-z

Aregbeshola, B. S., \& Khan, S. M. (2020). Out-of-pocket healthcare spending and its determinants among households in Nigeria: a national study. Journal of Public Health (Germany), 1-12. https://doi.org/10.1007/s10389-020-01199-x

Arsenijevic, J., Pavlova, M., Rechel, B., \& Groot, W. (2016). Catastrophic health care expenditure among older people with chronic diseases in 15 European countries. PLOS ONE, 11(7), 1-18. https://doi.org/10.1371/journal.pone.0157765

Baharin, M. F. A., Juni, M. H., \& Manaf, R. A. (2019). Assessing Progressivity of Out-of-Pocket Expenditures for Health Care: Evidence From Households in Malaysia. International Journal of Public Health and Clinical Sciences, 6(3), 187-202. https://doi.org/10.32827/ijphcs.6.3.187

Baird, K. (2016). High Out-of-Pocket Medical Spending among the Poor and Elderly in Nine Developed Countries. Health Services Research, 51(4), 1467-1488. https://doi.org/10.1111/14756773.12444

Barasa, E. W., Maina, T., \& Ravishankar, N. (2017). Assessing the impoverishing effects and factors associated with the incidence of catastrophic health care payments in Kenya. International Journal for Equity in Health, 16(1), 1-14. https://doi.org/10.1186/s12939-017-0526-x

Chiang, T. L. (1997). Taiwan's 1995 health care reform. Health Policy, 39(3), 225-239. https://doi.org/10.1016/S0168-8510(96)00877-9

Crystal, S., Johnson, R. W., Harman, J., Sambamoorthi, U., \& Kumar, R. (2000). Out-of-pocket health care costs among older Americans. Journals of Gerontology - Series B Psychological Sciences and Social Sciences, 55(1), 51-62. https://doi.org/10.1093/geronb/55.1.S51

DOSM. (2019). The Key Findings: Income, Poverty, Inequality, Expenditure, Basic Amenities.

Ebaidalla, E. M., \& Ali, M. E. M. (2019). Determinants and impact of household's out-of-pocket healthcare expenditure in Sudan: evidence from urban and rural population. Middle East Development Journal, 11(2), 181-198. https://doi.org/10.1080/17938120.2019.1668163

Galbraith, A. A., Wong, S. T., Kim, S. E., \& Newacheck, P. W. (2005). Out-of-pocket financial burden for low-income families with children: Socio-economic disparities and effects of insurance. Health Services Research, 40(6 I), 1722-1736. https://doi.org/10.1111/j.1475-

6773.2005.00421.x 
INTERNATIONAL JOURNAL OF ACADEMIC RESEARCH IN BUSINESS AND SOCIAL SCIENCES Vol. 10, No. 10, 2020, E-ISSN: 2222-6990 @ 2020 HRMARS

Golinowska, S., \& Tambor, M. (2012). Out-of-pocket payments on health in Poland: Size, tendency and willingness to pay. Society and Economy, 34(2), 253-271.

https://doi.org/10.1556/SocEc.34.2012.2.5

Gross, D. J., Alecxih, L., Gibson, M. J., Corea, J., Caplan, C., \& Brangan, N. (1999). Out-of-pocket health spending by poor and near-poor elderly Medicare beneficiaries. Health Services Research, 34(1 Pt 2), 241-254.

Grossman, M. (1972). On the Concept of Health Capital and the Demand for Health. Journal of Political Economy, 80(2), 223-255. https://doi.org/10.7312/gros17812-004.

Jayasooria, D. (2016). Towards 2030: Malaysia'S Development Agenda.

Ketsche, P., Adams, E. K., Wallace, S., Kannan, V. D., \& Kannan, H. (2011). Lower-income families pay A higher share of income toward national health care spending than higher-income families do. Health Affairs, 30(9), 1637-1646. https://doi.org/10.1377/hlthaff.2010.0712

Koris, R., Nor, N. M., Haron, S. A., Hamid, T. A., Nur, A. M., Shafie, A. A., ... Maimaiti, N. (2019). The Cost of Healthcare among Malaysian Community-Dwelling Elderly. Jurnal Ekonomi Malaysia, 53(1), 1-16.

Kumara, A. S., \& Samaratunge, R. (2016). Patterns and determinants of out-of-pocket health care expenditure in Sri Lanka: Evidence from household surveys. Health Policy and Planning, 1-14. https://doi.org/10.1093/heapol/czw021

Kwon, E., Park, S., \& McBride, T. D. (2018). Health Insurance and Poverty in Trajectories of Out-ofPocket Expenditure among Low-Income Middle-Aged Adults. Health Services Research, 53(6), 4332-4352. https://doi.org/10.1111/1475-6773.12974

Lu, X., \& White, H. (2014). Robustness checks and robustness tests in applied economics. Journal of Econometrics, 178(PART 1), 194-206. https://doi.org/10.1016/j.jeconom.2013.08.016

Mahumud, R. A., Sarker, A. R., Sultana, M., Islam, Z., Khan, J., \& Morton, A. (2017). Distribution and determinants of out-of-pocket healthcare expenditures in Bangladesh. Journal of Preventive Medicine and Public Health, 50(2), 91-99. https://doi.org/10.3961/jpmph.16.089

Mamun, S. A. K., Khanam, R., \& Rahman, M. M. (2018). The Determinants of Household Out-of-Pocket (OOP) Medical Expenditure in Rural Bangladesh. Applied Health Economics and Health Policy, 16(2), 219-234. https://doi.org/10.1007/s40258-018-0376-8

Manan, M. M., Ali, S. M., Khan, M. A. N., \& Jafarian, S. (2015). Estimation of out-of-pocket costs of patients at the Methadone Maintenance therapy clinic in Malaysia. Pakistan Journal of Pharmaceutical Sciences, 28(5), 1705-1711.

McNabb, R., \& Said, R. (2013). Trade Openness and Wage Inequality: Evidence for Malaysia. Journal of Development Studies, 49(8), 1118-1132. https://doi.org/10.1080/00220388.2013.794263

Minh, H. Van., Phuong, N. T. K., Saksena, P., James, C. D., \& Xu, K. (2013). financial burden of household out-of-pocket health expenditure in VietNam : Findings from the National Living Standard Survey 2002-2010. Social Science \& Medicine, 96, 258-263.

https://doi.org/10.1016/j.socscimed.2012.11.028

MNHA. (2016). Malaysia National Health Accounts, Health Expenditure Report 1997-2014.

NHMS. (2015). National Health \& Morbidity Survey, 2015 volume III). https://doi.org/10.31826/9781463229214-003

O'Brien, R. M. (2007). A Caution Regarding Rules of Thumb for Variance Inflation Factors. Quality \& Quantity, 41, 673-690. https://doi.org/10.1007/s11135-006-9018-6

Pallant, J. (2011). SPSS Survival Manual: a step by step guide to data analysis using IBM SPSS. Open 
INTERNATIONAL JOURNAL OF ACADEMIC RESEARCH IN BUSINESS AND SOCIAL SCIENCES

Vol. 10, No. 10, 2020, E-ISSN: 2222-6990 @ 2020 HRMARS

University Press.

Pandey, A., Clarke, L., Dandona, L., \& Ploubidis, G. B. (2018). Inequity in out-of-pocket payments for hospitalization in India: Evidence from the National Sample Surveys, 1995-2014. Social Science and Medicine, 201(October 2016), 136-147. https://doi.org/10.1016/j.socscimed.2018.01.031

Pannarunothai, S., \& Mills, A. (1997). The poor pay more: Health-related inequality in Thailand. Social Science and Medicine, 44(12), 1781-1790. https://doi.org/10.1016/S0277-9536(96)00287-0

PeKaB40. (2020). Skim peduli kesihatan untuk kumpulan B40. Retrieved https://www.pekab40.com.my/bm

Redzuan, H., Yakob, R., \& Isa, Z. (2016). Underinsurance in Malaysia: The application of the Monte Carlo simulation. Jurnal Pengurusan, 47(11), 131-141. http://dx.doi.org/10.17576/pengurusan2016-47-11

Sarker, A. R., Sultana, M., Ali, N., Akram, R., Sheikh, N., Mahumud, R. A., \& Morton, A. (2018). Cost comparison and determinants of out-of-pocket payments on child delivery care in Bangladesh. The International Journal of Health Planning and Management, 1-18. https://doi.org/10.1002/hpm.2615

Sene, L. M., \& Cisse, M. (2015). Catastrophic out-of-pocket payments for health and poverty nexus: evidence from Senegal. International Journal of Health Economics and Management, 15(3), 307328. https://doi.org/10.1007/s10754-015-9170-4

WHO. (2016). World Health Statistics - Monitoring Health for The SDGs. World Health Organization, 1-136. https://doi.org/10.1017/CBO9781107415324.004

Yildirim, J., Yilmaz, E., \& Korucu, N. (2011). The determinants of out-of-pocket payments: Evidence from selected hospitals in Ankara, Turkey. Applied Economics Letters, 18(12), 1159-1162. https://doi.org/10.1080/13504851.2010.528351

You, X., \& Kobayashi, Y. (2011). Determinants of out-of-pocket health expenditure in China: Analysis using china health and nutrition survey data. Applied Health Economics and Health Policy, 9(1), 39-49. https://doi.org/10.2165/11530730-000000000-00000

Yu, C. P., Whynes, D. K., \& Sach, T. H. (2006). Assessing progressivity of out-of-pocket payment: with illustration to Malaysia. International Journal of Health Planning and Management, 21, 193-210. https://doi.org/10.1002/hpm.845

Yunus, N. M., \& Said, R. (2016). Do higher levels of qualification lead to higher returns to education: Evidence from Malaysian education sector. International Journal of Economics and Financial Issues, 6(Special issue), 20-26. 